Article

\title{
Evaluation of Adaptation Practices in the Agriculture Sector of Bangladesh: An Ecosystem Based Assessment
}

\author{
Md. Arfanuzzaman *, Nabir Mamnun, Md. Syful Islam, Tanzina Dilshad and Md. Abu Syed \\ Bangladesh Centre for Advanced Studies (BCAS), House-10, Road-16a, Gulshan-1, Dhaka-1212, Bangladesh; \\ nabir.mamnun@bcas.net (N.M); syful.bcas@gmail.com (M.S.I.); tanzina.dilshad@gmail.com (T.D.); \\ abu.syed@bcas.net (M.A.S.) \\ * Correspondence: arfan@asia.com or thisisarfan@gmail.com; Tel.: +8802-985-2904; Fax: +8802-985-1417
}

Academic Editors: Angelika Ploeger, Sisira S. Withanachchi and Engin Koncagul

Received: 21 December 2015; Accepted: 28 January 2016; Published: 3 February 2016

\begin{abstract}
Climate changes imposed differential impacts on Bangladesh in the form of sea level rise, extreme events, and variability, which has enormous economic, environmental and social cost. Such impacts are assorted across the ecosystems of the Southwest, Northwest and Central region of the country. Among the different sectors, agriculture is comparatively more vulnerable to climate change impacts. In order to reduce the climate change induced loss and damage, a series of adaptation options have been being practiced by the people at the local level for many years, but the effectiveness, profitability, and sustainability of such adaptation options are still not too well investigated or understood. From this backdrop, the study intends to identify, prioritize and evaluate the adaptation options in the agriculture of different ecosystems of Bangladesh. It is found that the economic gain of adopting rice prawn farming, replantation of rice, and saline tolerant and short duration rice varieties are much higher than the other adaption options. Through investing $\$ 10$ in such adaptation options, $\$ 22, \$ 4, \$ 2$ and $\$ 2$ net return will be provided, respectively. Unavailability and less affordability are impeding the promotion of some effective adaption options, which require more attention from policy makers, while further research, demonstration and capacity building of the farmers will reduce vulnerability and build resilience.
\end{abstract}

Keywords: agriculture; adaptation evaluation; economics of climate change; climate vulnerability; southwest Bangladesh; ecosystem based assessment

\section{Introduction}

The Intergovernmental Panel on Climate Change (IPCC) pointed out in its Fifth Assessment Report (AR 5) that, compared to the average in the 20th century, average annual temperatures could rise by more than $2{ }^{\circ} \mathrm{C}$ over land in most of South Asia by the mid-21st century and exceed $3{ }^{\circ} \mathrm{C}$, and up to $6^{\circ} \mathrm{C}$ over high latitudes, by the late 21st century under a high-emissions scenario [1]. Under a low-emissions scenario, average temperatures could rise by less than $2{ }^{\circ} \mathrm{C}$ in the 21 st century, except at higher latitudes, which could be up to $3{ }^{\circ} \mathrm{C}$ warmer. In addition, globally, sea levels raised $1.7 \pm 0.2 \mathrm{~mm} / \mathrm{yr}$ from 1901 to 2010 as reported in the IPCC AR5, which is unchanged from the value in the IPCC Fourth Assessment Report (AR4) [2]. The report also indicated that the magnitude of sea level rise by the century's end implies significantly increased risks for coastal settlements of South Asia, as well as for coastal economies, cultures and ecosystems. The IPCC 2014 also finds on a global level that climate change could affect food security by the mid-21st century and most of the food insecure countries would continue to be in South Asia. Climate change impacts experiences in Bangladesh through different climate induced hazards. Due to the adverse effect of climate change, Bangladesh 
is at extreme risk of floods, tropical cyclones, sea level rise, salinity intrusion and drought, which makes it one of the most climate-vulnerable countries in the world [3,4]. The impacts of these hazards will affect several million in the country in the coming years. By 2100, a $0.71 \mathrm{~m}$ rise in global mean sea-level (with respect to 1980-1999 levels), up to $2.1 \times 103 \mathrm{~km}^{2}$ of Bangladeshi wetlands could be lost, representing up to $25 \%$ of the country's present wetland area [5].

Bangladesh would be the one of most adversely affected countries from climate change and the most damaging effects of climate change are floods, salinity intrusion, climate variability and droughts that are found to drastically distress the crop production each year, bringing a severe shock to the agriculture sector [3].

Agriculture is the dominant livelihood option across the Southwest, Northwest and Central region of Bangladesh and is the most vulnerable to the increasing frequency and intensity of extreme climate events such as floods, cyclones, storm surges, hailstorms, erratic and heavy rainfall, and salinity intrusion [6]. Climate change has differential impacts on agriculture, fisheries and water sector in these regions of Bangladesh. Climate change and climate variability are affecting the land use patterns, cropping systems, productivity, and optimum agriculture output [7]. They adversely affect the livelihoods, economic activities and environments of these regions, which make them vulnerable compared to other regions of the country [8]. Different forms of adaptation practices such as hard and soft adaptation are carried out around the world to reduce the loss and damage from extreme climate events and climate variability [9]. The viability, suitability and profitability of each adaptation options were not assessed to generate evidence that prove an adaptation option is viable and profitable. An endeavor has been made in this paper to identify and prioritize the adaptation options in the agriculture of different ecosystem and evaluate their appropriateness and effectiveness in terms of lessening climate change impacts from the grass roots level, which will help to generate knowledge and support the ecosystem based policy making in the Bangladesh agriculture sector.

Many adaption options have been practiced from the local to national levels across Bangladesh. Alauddin and Rahman [10] talked about a few adaptation practices such as flood shelters, cyclone shelters and school/college/madrasa building, and coastal and flood embankments in the flood and coastal areas, plinth raising of houses to protect houses and homesteads from the risks of climatic disasters in the coastal and floodplain areas, and tree plantations in the floodplains and drought prone areas around homesteads are the major effective structural adaptation measures of Bangladesh.

In order to cope with the climate change impact and minimize the loss and damage, different adaptation options are being carried out in the agriculture sector of Bangladesh. Floating bed crops/vegetables in the South-central and Southern areas, plant bed raising and dyke cropping at the shrimp gher is an old but effective practice nowadays [11,12]. Since each adaption option has some costs, this study focuses on the cost effectiveness, economic feasibility and sustainability for the evaluation of existing adaptation options.

\section{Objective of the Study}

The overall objective of this study is to evaluate the existing adaptation practices and their economic sustainability in the agriculture sector of Bangladesh in the face of climate change impacts and vulnerability. The specific objectives are:

(1) To identify and prioritize the existing adaptation practices in the agriculture of different ecosystems of Bangladesh;

(2) To assess the effectiveness of each adaptation option to minimize loss and damage in addition to negative externality of such adaptation measures;

(3) To evaluate the economic viability of prioritized adaptation options;

(4) To define the most sustainable adaptation option for the agriculture in the face of climate change impacts. 


\section{Study Areas}

The threats and impacts of climate change are multifaceted, multi-dimensional and multi-sectoral in Bangladesh. Thus, focus is given particularly in three selected districts, which represent three different ecosystems (coastal saline/surge prone areas, drought prone and riverine flood plain areas) in the Southwest, Northwest and Central part of the country. For each of the ecosystems, one case study district has been selected. The study districts are as Table 1.

Table 1. Study areas and their ecosystem and climatic factors.

\begin{tabular}{|c|c|c|c|}
\hline Location & District & Ecosystem & Climate Factors \\
\hline Southwest & Bagerhat & $\begin{array}{l}\text { Coastal-saline and } \\
\text { surge prone }\end{array}$ & $\begin{array}{c}\text { Salinity intrusion, sea-level rise, } \\
\text { cyclones/storm surges }\end{array}$ \\
\hline Northwest & Kushtia & Drought prone & Droughts \\
\hline Central & Shariatpur & Riverine floodplain & Floods, water logging \\
\hline
\end{tabular}

With $2{ }^{\circ} \mathrm{C}$ mean global temperature rise since pre-industrial levels, the combined effects of changes in major river flows, sea level rise (SLR), subsidence and local precipitation and evapotranspiration changes, results in the following impacts in study districts (Figure 1):

- Bagerhat-increase in salinity levels (by 0.5 to 2 Parts Per Thousand) and duration ( $>1$ PPT) doubles in northern part of district (Atharobanki and Madhumati Rivers);

- Kushtia-increase in monsoon and post-monsoon flows but little change in dry season flows due to siltation at Gorai River mouth;

- Shariatpur-average monsoon flood level increases by about $0.2-0.5 \mathrm{~m}$ and duration above danger level increases by about 25 days;

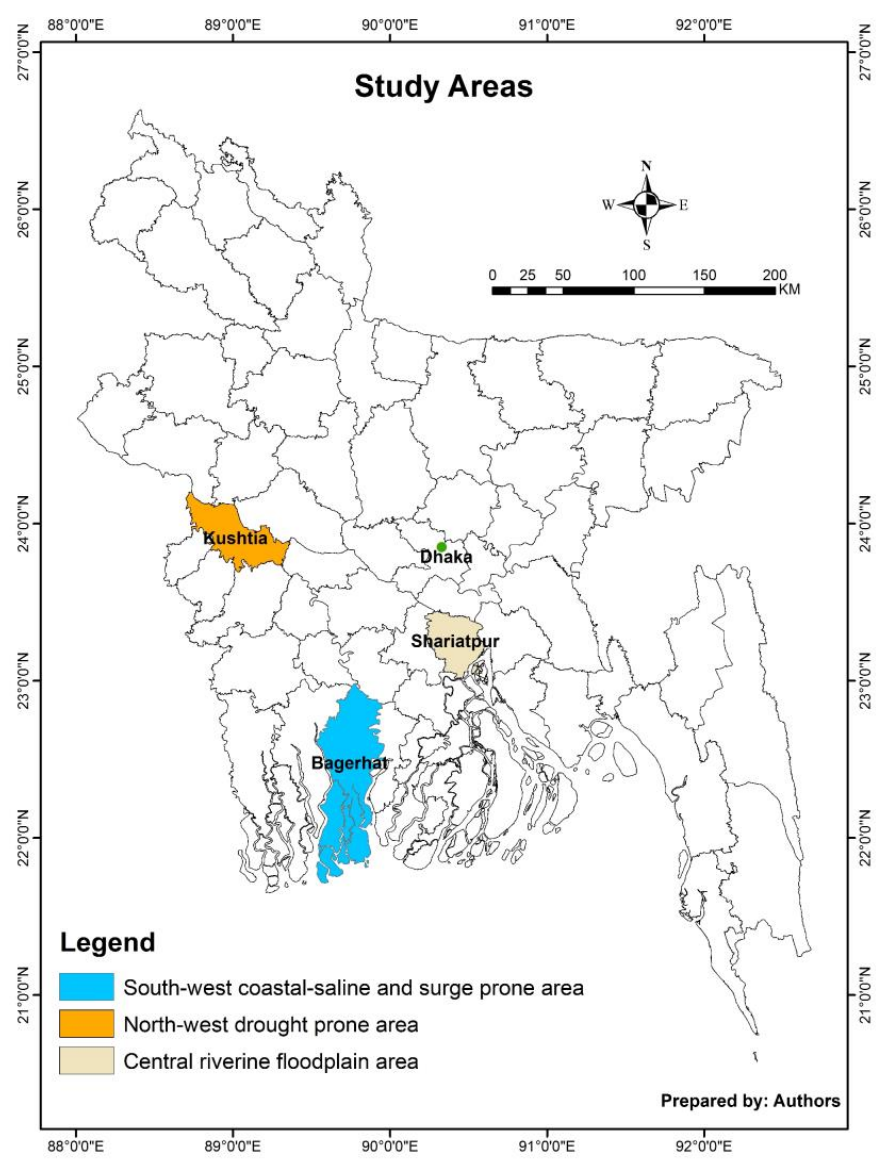

Figure 1. The map of Bangladesh showing the study areas. 


\section{Methodology and Data}

The study follows both quantitative and qualitative research methods to evaluate the adaptation options. The field research activities in the study areas considered primary data collection from the field to reflect farmers' perceptions regarding impacts and vulnerabilities in their production system and to identify the existing adaptation options which are being practiced at the local level agriculture. Two main methods were employed: questionnaire surveys and focus group discussions (FGDs). Questionnaire surveys were conducted with randomly selected farmers in the study areas using a semi-structured questionnaire. The sample size was 300 with 100 in each of the study areas. FGDs were carried out to have a greater understanding on climate change impacts and vulnerability in the local level and to validate the adaptation practices that emerged from the questionnaire survey. In total, nine FGDs were conducted with three in each of the study areas.

The existing adaption options in the agriculture sector against the climate change impacts and vulnerabilities that came out from the questionnaire surveys were shortlisted and prioritized based on the opinion of local communities and experts based on their competency to minimize the climate change impacts and economic loss. The shortlisted adaptation options were discussed with stakeholders and experts in a national level consultation workshop. The stakeholders and experts prioritized and ranked adaption options based on some specific criteria. The criteria for prioritization were effectiveness, external effects, availability, accessibility, affordability, and profitability/socio-economic gain. Finally, the prioritized adaptation options have been evaluated through cost benefit analysis, and adaptation decision matrix (ADM). In order to also carry out the cost benefit and economic analysis, data including price of different varieties, chemical and fertilizers, total production cost, loss and damage, and revenue are collected in quantitative form and then cost, benefit and other components are estimated. Finally, the ADM is prepared based on the key findings of each adaptation analysis. Here, ADM is used to evaluate the relative effectiveness and costs of adaptation options as well as providing the economic criterion of policy intervention in the areas of national and regional adaptation planning.

\section{Results and Findings}

\subsection{Existing Adaptation Practices in the Agriculture Sector}

Table 2 demonstrates the existing adaptation options against the climate stress in the study area. It appears that floods, droughts, storms/hailstorms, cold waves and salinity intrusion are the major climate stresses across the regions. The stress specific adaptation practices are collected from the questionnaire survey and ratified through FGDs. In the agriculture sector, nearly twenty-five adaption options are found from the study areas against the climate stresses, those are adopted by farmers to minimize the loss and damage. Adaptation practices differ from study area to study area and based on the technical and financial capacity of the farmers.

Table 2. Existing adaptation practices in the agriculture sector across regions.

\begin{tabular}{clc}
\hline Major Climate Stress & \multicolumn{1}{c}{ Adaptation Options } & Regions \\
\hline \multirow{2}{*}{ Floods } & $\begin{array}{l}\text { Shifting planting time, short duration rice } \\
\text { varieties, increasing the height of the mud wall, } \\
\text { using flood tolerant rice varieties, floating bed } \\
\text { agriculture, improved flood warning system } \\
\text { and communication }\end{array}$ & Bagerhaat, Shariatpur \\
\hline Droughts & $\begin{array}{l}\text { Short duration rice varieties, surface water } \\
\text { based irrigation, shifting planting time, drought } \\
\text { tolerant rice varieties, rainwater harvesting }\end{array}$ & Kushtia, Shariatpur \\
\hline Storms/hailstorms & $\begin{array}{l}\text { Replantation, early crop harvesting, short } \\
\text { duration varieties, Shifting planting time }\end{array}$ & Bagerhaat, Shariatpur \\
\hline
\end{tabular}


Table 2. Cont.

\begin{tabular}{clc}
\hline Major Climate Stress & \multicolumn{1}{c}{ Adaptation Options } & Regions \\
\hline Cold waves & $\begin{array}{l}\text { Using more chemical, fertilizer and pesticides, } \\
\text { vitamins such as Entergol, Asamil etc. are used } \\
\text { to the cold affected crops }\end{array}$ & $\begin{array}{c}\text { Bagerhaat, Kushtia, } \\
\text { Shariatpur }\end{array}$ \\
\hline Salinity intrusion & $\begin{array}{l}\text { Rice-prawn/shrimp farming, cultivating saline } \\
\text { tolerant varieties, rainwater harvesting, } \\
\text { desalinization }\end{array}$ & Bagerhaat \\
\hline Water logging & $\begin{array}{l}\text { Excavating the canals of surrounding field, } \\
\text { digging drain, excess water is withdrawn by } \\
\text { pump from the field }\end{array}$ & Bagerhaat \\
\hline Climate variability & $\begin{array}{l}\text { Use more fertilizer, apply additional pesticides } \\
\text { and insecticides }\end{array}$ & $\begin{array}{c}\text { Bagerhaat, Kushtia, } \\
\text { Shariatpur }\end{array}$ \\
\hline
\end{tabular}

\subsection{Adaptation Prioritization and Evaluation}

It appears that rainwater harvesting, rice-prawn farming in saline prone areas, short duration rice varieties, desalinization, and saline tolerant rice varieties are the top ranked adaptation options in the agriculture sector of Bangladesh. Afterwards, based on the availability of data and information, saline tolerant rice varieties, rice prawn farming, replantation, short duration rice varieties, usage of extra fertilizers and chemicals are evaluated (Table 3).

\subsubsection{Evaluation of Adopting Saline Tolerant Rice Varieties}

The anti-saline or saline tolerant rice varieties are common adaption practices nowadays in the Southwest salinity affected coastal regions of Bangladesh. The price of such a variety is only $\$ 1.54$ per $\mathrm{kg}$ whereas, the price of normal rice varieties is $\$ 2.8$ per $\mathrm{kg}$. The total cost of cultivating saline tolerant rice varieties is $\$ 732.64$ per hectare with productivity of 6.08 metric tons. If normal rice is cultivated in the saline prone area, nearly half of the rice production got damaged, which resulted in economic loss of nearly $\$ 420$ per ha. This is also called cost of inaction. If a saline tolerant rice variety is used instead of a normal variety, that amount of loss may not be faced by the farmers.

It appears in Table 4 that per ha net revenue of adopting a saline tolerant variety is $\$ 166$. The share of this adaptation cost is only $4 \%$ of total production expenditure. The benefit cost ration (BCR) is 1.2 of this adaptation option, which indicates that spending $\$ 1$ on a saline tolerant rice variety production system gives $\$ 1.2$ net return. Thus, a saline tolerant variety is a commercially profitable and economically viable adaptation option in the saline prone areas as well as in the Southwest region of Bangladesh.

Although saline tolerant varieties are a good adaptation option for the farmers for higher productivity and economic gain, these seeds are not usually available in the market place. Only the BRAC center provides saline tolerant varieties at the farmer level in the Southwest region. Thus, supply chain development along with ensuring availability and accessibility can boost the cultivation practice of this variety as an adaption option. 
Table 3. Prioritization of adaptation options.

\begin{tabular}{|c|c|c|c|c|c|c|c|c|c|}
\hline Climate stress & Adaptation Options & Effectiveness & $\begin{array}{l}\text { External } \\
\text { Effects }\end{array}$ & Availability & Accessibility & Affordability & $\begin{array}{c}\text { Profitability/ } \\
\text { Socio-Economic Gain }\end{array}$ & Total Mark & Rank \\
\hline \multirow[b]{2}{*}{ Floods } & \multirow{2}{*}{$\begin{array}{l}\text { Floating bed agriculture } \\
\text { Flood warning system } \\
\text { development }\end{array}$} & 4 & 4 & 2 & 3 & 4 & 2 & 19 & 8 \\
\hline & & 4 & 4 & 2 & 3 & 3 & 5 & 21 & 7 \\
\hline Droughts & $\begin{array}{l}\text { Drought tolerant } \\
\text { rice varieties }\end{array}$ & 3 & 4 & 3 & 3 & 3 & 5 & 21 & 7 \\
\hline \multirow[t]{3}{*}{ Storm/hailstorms } & Short duration rice varieties & 4 & 5 & 3 & 4 & 3 & 5 & 24 & 4 \\
\hline & Early crop harvesting & 3 & 4 & 4 & 5 & 4 & 2 & 22 & 6 \\
\hline & Shifting planting time & 4 & 4 & 4 & 4 & 4 & 4 & 24 & 4 \\
\hline \multirow{4}{*}{ Salinity intrusion } & \multirow{2}{*}{$\begin{array}{l}\text { Saline tolerant rice varieties } \\
\text { Rice-prawn farming in saline } \\
\text { prone areas }\end{array}$} & 4 & 3 & 4 & 4 & 3 & 5 & 23 & 5 \\
\hline & & 5 & 4 & 5 & 4 & 3 & 5 & 26 & 2 \\
\hline & Rainwater harvesting & 5 & 5 & 4 & 5 & 4 & 5 & 28 & 1 \\
\hline & Desalinization & 5 & 4 & 4 & 5 & 2 & 5 & 25 & 3 \\
\hline \multirow[b]{2}{*}{ Climate variability } & Use more fertilizer & 4 & 2 & 4 & 4 & 3 & 4 & 21 & 7 \\
\hline & $\begin{array}{c}\text { Use more } \\
\text { pesticides/Insecticides }\end{array}$ & 4 & 3 & 4 & 4 & 4 & 4 & 23 & 5 \\
\hline
\end{tabular}

Table 4. Economic analysis of saline tolerant rice varieties.

\begin{tabular}{cc}
\hline Crop: Rice & Amount (USD/\%) \\
\hline Cost of saline tolerant varieties Per ha & 29.3 \\
Total production cost per ha & 732.64 \\
Productivity per ha (M.ton) & 6.08 \\
Production loss without adaptation option & $46 \%$ \\
Cost of inaction & 419.79 \\
Share of adaptation cost on total investment & $4 \%$ \\
Revenue per ha (\$) & 898.71 \\
Net revenue per ha (\$) & 166.06 \\
Benefit cost ration & 1.2 \\
\hline
\end{tabular}




\subsubsection{Evaluation of Rice-Prawn Farming}

Rice prawn farming is a widely practiced adaption option against flood and salinity in the Southwest region. In the same unit of land, a canal is excavated surrounding the rice field to cultivate the prawn, and the rest of the areas are used for rice cultivation. The rain water can also be stored in the canal and used for irrigation purposes later. The total cost of producing rice-prawn in a hectare of land overall is $\$ 793.7$ is required. If rice-prawn farming is not practiced in the flood and saline prone areas, nearly $18 \%$ of production is lost from per ha of land, which incurs total economic loss of $\$ 232$. Integrating rice-prawn farming can effectively compensate the loss and generate net revenue of $\$ 1,739$ per ha for the farmers. Table 5 demonstrates the average productivity of rice-prawn farming is $10.93 \mathrm{M}$. ton, which is notably higher than any kind of rice cultivation in Bangladesh. The BCR of such adaption options is 3.2. This signifies that single dollar spending on rice-prawn farming as an adaptation option can provide more than triple times the financial benefit to the farmers.

As an adaptation option, rice-prawn farming offers more benefits to society as a whole. It helps to decrease the seasonal food shortage from the saline and flood prone areas. Since it is more profitable than rice farming, the economic status as well as the well-being of the farmer increases. Simultaneously, rice-prawn farming also can contribute to the prawn export earnings for Bangladesh. Some problems are also involved with this adaptation option. The juvenile prawn is not available all of the time. Thus, it needs to be collected from other regions such as Noakhali and Barishal. There is also a question of quality juvenile prawn. Hence, emphasis needs to be given to extensively produce the juvenile prawn locally to diminish the seasonal crisis and ensure the quality. Some institutional support may be useful in this regard.

Table 5. Economic analysis of rice-prawn farming.

\begin{tabular}{cc}
\hline Crop: Rice & Amount (USD/\%) \\
\hline Cost of rice varieties and prawn per ha & 82.77 \\
Total production cost per ha & 793.7 \\
Avg. productivity per ha (M.ton) & 10.93 \\
Production loss without adaptation option & $18.04 \%$ \\
Cost of inaction & 232.01 \\
Share of adaptation cost on total investment & $10.43 \%$ \\
Revenue per ha (\$) & $2,532.52$ \\
Net revenue per ha (\$) & 1,739 \\
Benefit cost ration & 3.2 \\
\hline
\end{tabular}

\subsubsection{Evaluation of Replantation}

Due to extreme climate events such as storms/hailstorms, juvenile crops got damaged and no output can be obtained from this damaged crop. In this case, farmers replant the crop to get the production and reduce the financial loss. Table 6 represents the gain and loss of replanting rice and jute as an adaptation option. If farmers do not plant the crop again after damaging the juvenile crops, full production gets lost and farmers face economic loss worth $\$ 890.7$ per ha for rice and $\$ 1,079.43$ for jute. The estimation shows that the total cost of replantation for rice is $\$ 636.23$ and the net gain is $\$ 255$ per ha, whereas jute requires \$952.44 replantation cost per ha and generates a net gain of \$127. It appears that BCR for jute and rice are 1.13 and 1.4, respectively. Due to higher cost of replantation, the BCR of jute is relatively lower than rice. 
Table 6. Economic analysis of replantation.

\begin{tabular}{ccc}
\hline Crop: Rice and Jute & Rice (USD/\%) & Jute (USD/\%) \\
\hline Cost of seeds per ha & 53.73 & 37.79 \\
Total cost of replantaion per ha & 636.23 & 952.44 \\
Productivity per ha (M.ton) & 5.9 & 2 \\
Production loss without adaptation option & $100 \%$ & $100 \%$ \\
Cost of inaction & 890.7 & $1,079.43$ \\
Share of adaptation cost on total investment & $0.0844 \%$ & $0.0396 \%$ \\
Revenue per ha (\$) & 890.7 & $1,079.4$ \\
Net revenue per ha (\$) & 255 & 127 \\
Benefit cost ration & 1.4 & 1.13 \\
\hline
\end{tabular}

Replantation can be possible if extreme events occur within 30-45 days of crop plantation. When farmers tend to plant the crop again, they face a seed crisis due to unavailability of seeds in the marketplace. After extreme events, very few people receive agricultural inputs such as seeds, fertilizer, etc. free from the Government. It is reported that when farmers go for replantation following extreme events, productivity of such crops go down due to loss in soil fertility and weather change. Hence, optimum production cannot be attained.

\subsubsection{Evaluation of Adopting Short Duration Rice Varieties}

In order to protect the crops from flood, storms/hailstorms, droughts and cold temperatures, farmers use short duration varieties as an adaptation option. The cropping life of such rice varieties is usually 20-25 days less than the regular varieties. Table 7 shows that, per ha, the cost of short duration rice varieties is only $\$ 9.77$, which is only $1 \%$ of total production cost. The total production cost of short duration rice varieties is close to $\$ 1,016$ per ha, and it generates net revenue of $\$ 171.7$ to the farmers. It is found in the estimation that $\mathrm{BCR}$ of short duration rice varieties is 1.2, meaning that spending one dollar on such an adaption choice provides a return of $\$ 1.2$. Alternatively, every $\$ 5$ spending on this adaptation measure can generate $\$ 1$ net profit. Thus, this adaption option is profitable and economically feasible.

Table 7. Economic analysis of adopting short duration rice varieties.

\begin{tabular}{cc}
\hline Crop: Rice & Amount (USD/\%) \\
\hline Cost of short duration varieties per ha & 9.77 \\
Total production cost per ha & $1,015.94$ \\
Productivity per ha (M.ton) & 6.2 \\
Cost of inaction & $70 \%$ \\
Production loss without adaptation option & 831.36 \\
Share of adaptation cost on total investment & $1 \%$ \\
Revenue per ha (\$) & $1,187.66$ \\
Net revenue per ha $(\$)$ & 171.72 \\
Benefit cost ration & 1.2 \\
\hline
\end{tabular}

Although the price of short duration rice varieties is very low compared to other rice varieties, it requires more agricultural inputs such as chemicals, fertilizers, pesticides and insecticides. This increases the cost of production and reduces the net revenue per ha. Short duration rice varieties saves $70 \%$ production loss from extreme climate events.

\subsubsection{Evaluation of Applying Extra Chemicals and Fertilizer to Face a Cold Spell}

In winter season, when a cold spell occurs, it injures the crop and shrinks the production level. Consequently, optimum production is not achieved from the farmland. Hence, in order to protect the crops from cold spells, farmers extensively use chemicals and fertilizer in the field. Table 8 shows 
that per ha cost of using additional chemicals and fertilizer is nearly $\$ 38$, which is $4.29 \%$ of total production cost. This adaption option can save $50 \%$ production loss per ha. If additional chemicals and fertilizer are not applied in the soil, $\$ 443$ worth of wheat production is missed from the land. Moreover, the cost of additional chemicals and fertilizer amplifies the production cost and trims down the net benefit. The BCR of this adaption option is found to be relatively marginal, which is only 1.1, meaning that per dollar spending on this cultivation method gives a return of $\$ 1.1$. In other words, every $\$ 10$ of spending on this farming technique can provide $\$ 1$ net benefit to the farmers. Furthermore, using more chemicals and fertilizer is not a sustainable adaptation option. It increases the green house's gas emission, adversely affects the environmental health and also largely contributes to the land degradation.

Table 8. Economic analysis of applying extra chemicals and fertilizers to face cold spells.

\begin{tabular}{cc}
\hline Crop: Wheat & Amount (USD) \\
\hline Cost of chemicals and fertilizer per ha & 38.09 \\
Total production cost per ha & 888.95 \\
Productivity per ha (M.Ton) & 3.7 \\
Production loss without adaptation & $50 \%$ \\
Cost of inaction & 443 \\
Share of adaptation cost on total investment & $4.29 \%$ \\
Revenue per ha (\$) & 946.02 \\
Net revenue per ha (\$) & 57.07 \\
Benefit cost ration & 1.1 \\
\hline
\end{tabular}

\subsection{Adaptation Decision Matrix (ADM)}

The economic feasibility and technical viability of a series of adaption options can be obtained from the ADM. Both quantitative and qualitative sets of relevant information of a particular adaptation choice can be analyzed and compared through the ADM for meticulous review and in order to make decisions. It is evident from Table 9 that per ha cost of rice prawn farming, net return and BCR are much higher compared to other adaptation options. No notable shortcomings are found for this adaptation option. The only problem is found that juvenile prawn is not available during the extreme event, which hinders the local level adaptation decision. Thus, among the adaption options, rice prawn farming can be suggested as a most favorable adaptation option. After that, replantation of rice crops and using saline tolerant varieties are also found to be economically feasible and commercially profitable (Table 9). Extensive research should be carried out to develop saline tolerant varieties to reduce chemicals and fertilizer requirements, and it should be available in the marketplace. Although, the agriculture of coastal-saline and surge prone ecosystems are found to be more vulnerable to salinity intrusion and storms, $\mathrm{BCR}$ and net return are found to be much higher in those ecosystems compared to the drought prone and riverine floodplain ecosystems. 
Table 9. ADM for the agriculture sector.

\begin{tabular}{|c|c|c|c|c|c|c|c|c|}
\hline Adaptation Options & $\begin{array}{l}\text { Per ha Cost of } \\
\text { Adopting (\$) }\end{array}$ & BCR & $\begin{array}{l}\text { Net Return on } \\
\text { Each } \$ 10 \\
\text { Spending (\$) }\end{array}$ & $\begin{array}{l}\text { Net Profit } \\
\text { per ha }(\$)\end{array}$ & $\begin{array}{c}\text { Share on } \\
\text { Total Cost }(\%)\end{array}$ & Availability & Strength & Weakness \\
\hline Saline tolerant rice varieties & 29.3 & 1.2 & 2 & 166 & 4 & Less available & $\begin{array}{l}\text { More productivity, } \\
\text { Saline tolerant }\end{array}$ & $\begin{array}{l}\text { More chemical and } \\
\text { fertilizer are required }\end{array}$ \\
\hline Rice prawn farming & 82.77 & 3.2 & 22 & 1739 & 10.43 & $\begin{array}{l}\text { Juvenile prawn is not } \\
\text { available on time }\end{array}$ & $\begin{array}{l}\text { Highly profitable } \\
\text { and effective }\end{array}$ & $\mathrm{n} / \mathrm{a}$ \\
\hline Replantation (Jute) & 37 & 1.13 & 1.3 & 127 & 3.96 & Less available & $\begin{array}{l}\text { Increase financial } \\
\text { solvency }\end{array}$ & Less productive \\
\hline Replantation (Rice) & 53 & 1.4 & 4 & 255 & 8.44 & Less available & $\begin{array}{l}\text { Reduce seasonal } \\
\text { food shortage }\end{array}$ & $\mathrm{n} / \mathrm{a}$ \\
\hline $\begin{array}{l}\text { Short duration } \\
\text { rice varieties }\end{array}$ & 9.77 & 1.2 & 2 & 172 & 1 & Moderately available & $\begin{array}{l}\text { Not affected by flood, } \\
\text { drought, storm }\end{array}$ & $\begin{array}{l}\text { More chemical, fertilizer } \\
\text { and pesticides are required }\end{array}$ \\
\hline $\begin{array}{l}\text { Using extra chemical } \\
\text { and fertilizer }\end{array}$ & 38.09 & 1.1 & 1 & 57 & 4.29 & Moderately available & Effective & Environmental degradation \\
\hline
\end{tabular}




\section{Conclusions and Recommendations}

It is evident that climate change adaptation practices have some costs and also fuel the cost of production in the agriculture sector, which may not be always affordable to the poor and marginal farmers of Bangladesh and other climate vulnerable lesser-developed and smaller island countries of the world. Though farmers of Bangladesh have made very insignificant contribution to causing climate change; however, they are experiencing multiple and compounded climate stresses, variability and climate induced natural disasters in the agriculture sector as well as other sectors of the economy. Here, the agriculture sector is more susceptible because of small scale farming systems, low capacity/capital of farmers, weak technical efficiency, lack of large scale investment and presence of paradoxes of bumper harvest. The findings of this study can be used for calling out for other countries with similar climate change impacts, but, in such cases, adaptation options are suggested to evaluate economically as a prerequisite. Finally, to promote adaptations in agriculture and increase the sectoral productivity and reduce climate induced loss and damage under different ecosystems, following the steps below will be helpful for Bangladesh and other countries with similar context:

(1) Mainstreaming climate change adaptation in national levels through sustainable development policies and strategies are suggested for fostering ecosystem based adaptation.

(2) Building partnerships with local and international organizations for the implementation of regional agriculture development programs and integrating adaption plants with it.

(3) Developing effective community based and participatory early warning systems and early action steps to reduce loss and damage.

(4) Strengthening financial instruments (e.g., climate risk insurance, climate change adaptation clearing houses, soft loans for poor and marginal farmers) for climate change adaptation.

(5) Building capacity (institutional governance, infrastructure and human resources) and raising awareness to increase understanding of climate change in the agriculture sector.

(6) Carrying out more research to generate evidence based knowledge in the ecosystem based agricultural adaptations.

(7) Promoting and availing ecosystem based adaption options in the least costly way.

(8) Defining extreme event induced critical moments to reduce the severity of loss and damage.

(9) Promoting juvenile prawn farming in the local level to ensure the availability in the adaptation period.

(10) Ensuring the availability of agriculture input such as saline and drought prone varieties, chemical and fertilizer in the marketplace during critical climate moments and adaptation period as well. So that, farmers can adapt quickly and effectively.

(11) Carrying out extensive research to improve the Short duration and saline tolerant rice variety. So that requirement of using extra fertilizer and chemical will be reduced. As a result overall cost of production, and land and environmental degradation will be declined.

(12) Making the agriculture inputs such as saline and drought prone variety, chemical and fertilizer affordable and accessible in the marketplace. So that farmers can take the adaption decision fastly during the critical moments. Arrangement of soft loan can be effective such case.

(13) Intensifying the assessment of disaster risk, preparation and implementation of preparedness, responses and recovery plans.

Thus, in order to enhance the adaptive capacity and resilience building mentioned above, national level policy support is required in the agriculture sector. As per the IPCC's predictions, future impacts of climate change will be more devastating in Bangladesh as well as in other low lying small island nations. Thus, the study calls for national level support in ecosystem based adaptations. Otherwise, in the future, farmers will not be encouraged to invest in adaptations during climate induced critical moments. Moreover, a mix of actions coordinated at international, national and regional levels would also be required to build resilience and reduce vulnerability in the agriculture sector of Bangladesh. Technological advancement can reduce the climate change impacts more 
effectively and build robust resilience in the agriculture sector. Invention and promotion of affordable technology and climate resilient farming systems are also required to drastically reduce the loss and damage from the agriculture sector.

Acknowledgments: The research leading to these results has received funding from the European Union's and European Atomic Energy Community's Seventh Framework Programme ([FP7/2007-2013] [FP7/2007-2011]) under grant agreement No. [282746] related project "Quantifying Projected Impacts under $2{ }^{\circ} \mathrm{C}$ Warming (IMPACT2C)". The project has been carried out by Bangladesh Centre for Advanced Studies (BCAS) in collaboration with 27 other European Centre of Excellence and partner institutions in Bangladesh and Niger. We acknowledge the research works undertaken by our IMPACT2C partners which were the basis for this particular study. We also acknowledge the BCAS and Wageningen University Research (WUR) for their support in carrying this study.

Author Contributions: First author developed the research contents and methodology and conduct the data analysis and writing. Second author contributed to the methodology, contents and perform the experiment. Third and fourth author contributed to data collection literature review and analysis. Fifth author provided overall guideline and edited the paper.

Conflicts of Interest: The authors declare no conflict of interest.

\section{References}

1. IPCC. Climate Change 2014: Impacts, Adaptation, and Vulnerability. Part A: Global and Sectoral Aspects. In Contribution of Working Group II to the Fifth Assessment Report of the Intergovernmental Panel on Climate Change; Field, C.B., Barros, V.R., Eds.; Cambridge University Press: New York, NY, USA, 2014; pp. 1-32.

2. Brown, S.; University of Southampton, Southampton, UK. Projected Sea-Level Rise and Subsequent Wetland Loss in Bangladesh-A Short Report Prepared as Part of the EU FP7 Project, IMPACT2C for WP13: Impact, Vulnerability and Most Vulnerable Regions. 2015.

3. Government of the People's Republic of Bangladesh: National Adaptation Programme of Action (NAPA). Available online: http://unfccc.int/resource/docs/napa/ban01.pdf (accessed on 21 December 2015).

4. Community Based Adaptation in Action: A Case Study from Bangladesh, Improved Adaptive Capacity to Climate Change for Sustainable Livelihoods in Agriculture Sectors. Available online: http://www.fao.org/ 3/a-i0481e.pdf (accessed on 21 December 2015).

5. Brown, S.; Nicholas, R.; Caeser, J.; Lowe, J.; Hinkel, J.; Lincke, D.; University of Southampton, Southampton, UK. Future Sea Level Rise Scenario for Bangladeh: A Focus of $2{ }^{\circ} \mathrm{C}-\mathrm{A}$ Short Report Prepared as Part of the EU FP7 Project, IMPACT2C for WP13: Impact, Vulnerability and Most Vulnerable Regions. 2015.

6. Mainuddin, K.; Rahman, A.; Islam, N.; Quasem, S. Planning and Costing Agriculture's Adaptation to Climate Change in the Salinity-Prone Cropping System of Bangladesh; International Institute for Environment and Development (IIED): London, UK, 2011.

7. Government of the People's Republic of Bangladesh. Bangladesh Climate Change Strategy and Action Plan 2009. Available online: http://www.climatechangecell.org.bd/Documents/climate_change_strategy2009.pdf (accessed on 21 December 2015).

8. Huq, N.; Huge, J.; Boon, E.; Gain, A.K. Climate Change Impacts in Agricultural Communities in Rural Areas of Coastal Bangladesh: A Tale of Many Stories. Sustainability 2015, 7, 8437-8460. [CrossRef]

9. Asian Development Bank. Adapting to Climate Change: Strengthen the Climate Resilience of the Water Sector Infrastructure in Khulna, Bangladesh. Available online: http://adb.org/sites/default/files/pub/ 2011/adapting-climate-change-ban.pdf (accessed on 21 December 2015).

10. Alauddin, S.M.; Rahman, K.F. Vulnerability to Climate Change and Adaptation Practices in Bangladesh. J. SUB 2013, 4, 25-42.

11. Adger, W.N.; Nelson, D.; Brown, K. Adaptation to environmental change: Contributions of a resilience framework. Annu. Rev. Environ. Resour. 2007, 32, 395-419.

12. Alam, M.; Ahammad, R.; Nandy, P.; Rhaman, S. Coastal Livelihood Adaptation in Changing Climate: Bangladesh Experience of NAPA Priority Project Implementation. In Climate Change Adaptation Actions in Bangladesh; Shaw, R., Ahammad, R., Eds.; Springer Japan: Tokyo, Japan, 2013; pp. 253-276. 